\title{
Penile gangrene as a sign of uncontrolled diabetes mellitus
}

\author{
Samer Al Hadidi, ${ }^{1}$ Raad A Haddad ${ }^{2}$ Firas Abed ${ }^{2}$ Ghassan Bachuwa ${ }^{3}$
}

${ }^{1}$ Department of Internal Medicine, Michigan State University, Flint, Michigan, USA ${ }^{2}$ Department of Internal Medicine, Hurley Medical Center, Flint, Michigan, USA ${ }^{3}$ Hurley Medical Center, Flint, Michigan, USA

\section{Correspondence to} Dr Ghassan Bachuwa, gbachuw2@hurleymc.com

Accepted 23 January 2016
CrossMark

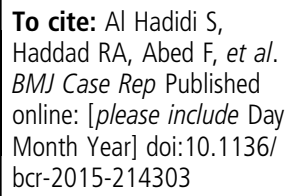

\section{DESCRIPTION}

A 33-year-old African-American man with a previous medical history of type II diabetes mellitus and tobacco abuse presented to our outpatient clinic because of a penile lesion. The lesion started 1 month prior to presentation. The patient reported a history of minor injury while zipping his pants, which resulted in slight redness at the tip of his glans penis, progressing to blackish discolouration. He was sexually active with one female partner and reported infrequent oral sex. He had no penile discharge, no pain and no urinary symptoms.

His diabetes mellitus was diagnosed 3 years prior to presentation. He was non-compliant with oral hypoglycaemic medications. Examination showed normal vital signs and superficial dry gangrene with no drainage (figure 1). He had no inguinal lymphadenopathy. The reminder of his physical examination, including cardiovascular examination, was normal. Lab investigations showed haemoglobin A1c of 12.9\% (reference 0-5.7\%). Comprehensive metabolic panel, complete blood count and urinalysis were normal.

The patient was started on insulin therapy and frequent local wound care with silver sulfadiazine. Two months later, his lesion totally resolved (figure 2). Haemoglobin A1c 4 months later was 5.8\%.

Penile gangrene that results from vascular trauma is a rare complication of diabetes mellitus. Penile calciphylaxis resulting from vascular calcification in patients with end-stage renal disease and diabetes is well established. ${ }^{1}$ Management of penile gangrene depends on the cause and includes conservative

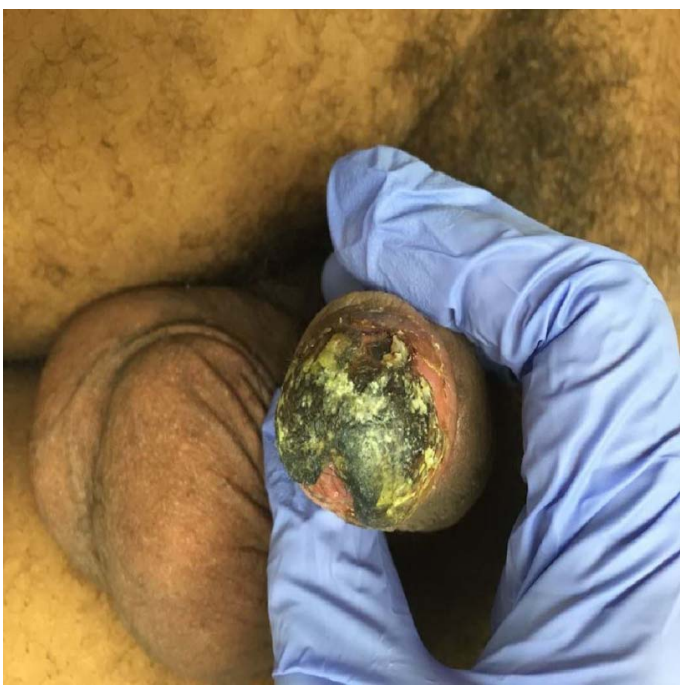

Figure 1 Penile gangrene before treatment.

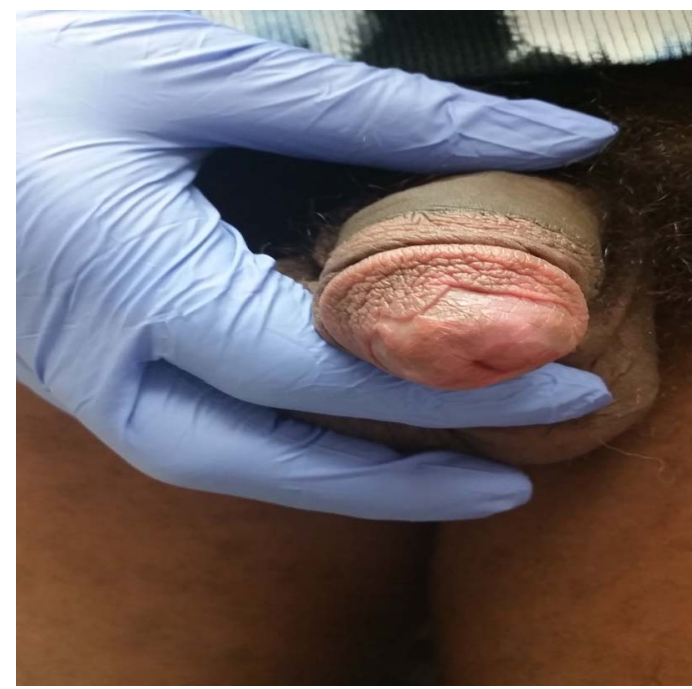

Figure 2 Resolved penile gangrene after treatment.

measures. ${ }^{2}$ Surgical intervention may be needed in patients who experience superimposed complications such as infections, extension of the gangrene or failure of conservative management. ${ }^{3}$

\section{Learning points}

- Penile gangrene can result from vascular trauma in patients with uncontrolled diabetes mellitus.

- Superficial penile gangrene is usually reversible with local wound care and optimal diabetic control.

Contributors SAH took care of the patient during hospital admission, reviewed the literature and wrote the manuscript. RAH followed the patient in the outpatient setting and helped write the manuscript. FA and GB reviewed the literature and the contents of the manuscript.

Competing interests None declared.

Patient consent Obtained.

Provenance and peer review Not commissioned; externally peer reviewed.

\section{REFERENCES}

1 Stein M, Anderson C, Ricciardi R, et al. Penile gangrene associated with chronic renal failure: report of 7 cases and review of the literature. J Urol 1994;152:2014-16.

2 Lewis DC, Mathialahan T, Ray D. Conservative management of penile gangrene. $\mathrm{Br} J$ Urol 1995;75:412-13.

3 Kumbkarni Y, Magsino CH, Dandona P. A diabetic patient with a black penile tip. J Diabetes Complicat 1999;13:316-19. 
Copyright 2016 BMJ Publishing Group. All rights reserved. For permission to reuse any of this content visit http://group.bmj.com/group/rights-licensing/permissions.

BMJ Case Report Fellows may re-use this article for personal use and teaching without any further permission.

Become a Fellow of BMJ Case Reports today and you can:

- Submit as many cases as you like

- Enjoy fast sympathetic peer review and rapid publication of accepted articles

- Access all the published articles

- Re-use any of the published material for personal use and teaching without further permission

For information on Institutional Fellowships contact consortiasales@bmjgroup.com

Visit casereports.bmj.com for more articles like this and to become a Fellow 